\title{
The climate penalty for clean fossil fuel combustion
}

\author{
W. Junkermann ${ }^{1}$, B. Vogel ${ }^{2}$, and M. A. Sutton ${ }^{3}$ \\ ${ }^{1}$ Karlsruhe Institute of Technology, IMK-IFU, Garmisch-Partenkirchen, Germany \\ ${ }^{2}$ Karlsruhe Institute of Technology, IMK-TRO, Karlsruhe, Germany \\ ${ }^{3}$ Centre for Ecology and Hydrology, Edinburgh Research Station, Penicuik, Midlothian, UK
}

Received: 8 June 2011 - Published in Atmos. Chem. Phys. Discuss.: 1 September 2011

Revised: 3 December 2011 - Accepted: 5 December - Published: 20 December 2011

\begin{abstract}
To cope with the world's growing demand for energy, a large number of coal-fired power plants are currently in operation or under construction. To prevent environmental damage from acidic sulphur and particulate emissions, many such installations are equipped with flue gas cleaning technology that reduces the emitted amounts of sulphur dioxide $\left(\mathrm{SO}_{2}\right)$ and nitrogen dioxide $\left(\mathrm{NO}_{2}\right)$. However, the consequences of this technology for aerosol emissions, and in particular the regional scale impact on cloud microphysics, have not been studied until now. We performed airborne investigations to measure aerosol size distributions in the air masses downwind of coal-fired power installations. We show how the current generation of clean technology reduces the emission of sulphur and fine particulate matter, but leads to an unanticipated increase in the direct emission of ultrafine particles (1-10 nm median diameter) which are highly effective precursors of cloud condensation nuclei (CCN). Our analysis shows how these additional ultrafine particles probably modify cloud microphysics, as well as precipitation intensity and distribution on a regional scale downwind of emission sources. Effectively, the number of small water droplets might be increased, thus reducing the water available for large droplets and rain formation. The possible corresponding changes in the precipitation budget with a shift from more frequent steady rain to occasionally more vigorous rain events, or even a significant regional reduction of annual precipitation, introduce an unanticipated risk for regional climate and agricultural production, especially in semi-arid climate zones.
\end{abstract}

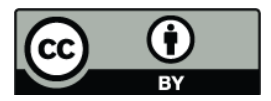

Correspondence to: W. Junkermann (wolfgang.junkermann@kit.edu)

\section{Introduction}

Most global climate model based studies conclude that anthropogenic sulphur aerosols are beneficial for cooling the earth and thus counteracting the global warming effect of greenhouse gases (Lelieveld and Heinzenberg, 1992). A reduction of sulphur dioxide emissions, such as by cleaning of stack flue gas emissions from fossil fuel burning power plant or from refineries, is thus claimed to accelerate global warming (Arneth et al., 2009; Shindell and Faluvegi, 2009). The basis of this beneficial climate effect of sulphur emissions is the assumption that power plants emit sulphur as $\mathrm{SO}_{2}$ which then slowly reacts to form sulphate aerosol within several days with the sulphur accumulating primarily on already existing particle surfaces, increasing the scattering of solar radiation by aerosol (Arneth et al., 2009). This process takes several days, distributing sulphur compounds in the atmosphere from regional-scale emissions to a continental to global scale (Manteklow et al., 2009).

Although direct gas-to-particle conversion and a new production of ultrafine particles from $\mathrm{SO}_{2}$ emissions is considered to be of minor importance to the production of sulphate aerosols in current models (Lohmann et al., 1999, 2000; Liepert et al., 2004; Kazil et al., 2010) and emission estimates (Stier et al., 2006) which form the basis of the model calculations (Kazil et al., 2010), there is evidence of a pronounced relation between new particle production (NPP) by nucleation and sulphuric acid concentrations (Paasonen et al., 2010; Birmili et al., 2003). This indicates the importance of sulphuric acid to the aerosol number budget. New particle production is the source of the ultrafine (Aitken mode) particles which enhance cloud albedo via the number of CCN. At first sight, ultrafine particles from NPP are therefore considered to be beneficial for the Earth's radiation budget by increasing cloud albedo, especially when they appear over the ocean (Kazil et al., 2010; Jones et al., 2009). However,

Published by Copernicus Publications on behalf of the European Geosciences Union. 
the magnitude of this effect is still uncertain (Wang et al., 2011).

Models are not yet able to quantify precisely this radiative impact (Feingold and Siebert, 2009). Furthermore, and adding to the uncertainty, cloud process models (Khain, 2009) also anticipate other concurrent climate effects like a modification of precipitation from warm clouds, which leads to a suppression of low-intensity steady rain and a shift to more vigorous downpours from clouds involving an ice phase (Konwar et al., 2010). Thus, cloud modification by anthropogenic $\mathrm{CCN}$ not only has radiative effects, but may also result in secondary climate impacts via the three-dimensional redistribution of water vapour amount and precipitation intensity on larger scales, because modern, "clean", power plants emit a reduced mass of $\mathrm{SO}_{2}$, but higher numbers of extremely small, nm-sized, ultrafine sulphate aerosols (Junkermann et al., 2011). These tiny aerosols $(\sim 1 \mathrm{~nm}$ diameter $)$ are produced inside the power plant stack in the cleaning chain, with up to $3 \%$ of the initial $\mathrm{SO}_{2}$ converted into $\mathrm{SO}_{3}$ - or $\mathrm{H}_{2} \mathrm{SO}_{4}$ (Murphy, 2007). To clean the flue gas fly ash, fine and coarse particles containing large fractions of the sulphur content, are removed. In a second step nitrogen dioxide is converted by selective catalytic reduction (SCR) to $\mathrm{N}_{2}$ to prevent the production of nitric acid. The different processes, especially the catalytic production, leading to $\mathrm{SO}_{3} / \mathrm{H}_{2} \mathrm{SO}_{4}$ within the plant are described in detail in Srivastava et al., (2004). The $\mathrm{H}_{2} \mathrm{SO}_{4}$ is emitted as an opaque "blue plume" consisting of nm size droplets. Larger fly ash particles as present in the plumes of old dirty power plants are missing for deposition. Thus these tiny aerosols survive and grow rapidly in the atmosphere (Junkermann et al., 2011). Sulphuric acid particles become active as CCN already at a size of $\sim 50 \mathrm{~nm}$ (Hamed et al., 2010; Adams and Seinfeld, 2003). Over continental areas they can be expected to have a less "beneficial" climate side effect than $\mathrm{SO}_{2}$ emissions, by affecting large-scale precipitation distribution (Junkermann et al., 2009; Flossmann and Wobrock, 2010). This is illustrated in Fig. 1, where the ultrafine aerosols alter the number of $\mathrm{CCN}$ and create brighter clouds (Twomey, 1974).

\section{Experimental}

Airborne measurements of ultrafine particles in the Karlsruhe (Germany) and Xilinhot (Inner Mongolia) power plant plumes, as well as over the boreal forest in Finland (O'Dowd et al., 2009) were performed using an ultralight aircraft (Junkermann, 2001) as a platform. Measurements in Australia (Junkermann et al., 2009) were made with a motorised glider (DIMONA, HK36) provided and operated by Airborne Research Australia (http://www.airborneresearch.org. $\mathrm{au}$ ). Instrument installations for the determination of aerosol size distributions on both aircraft are summarised in the following table (Table 1).
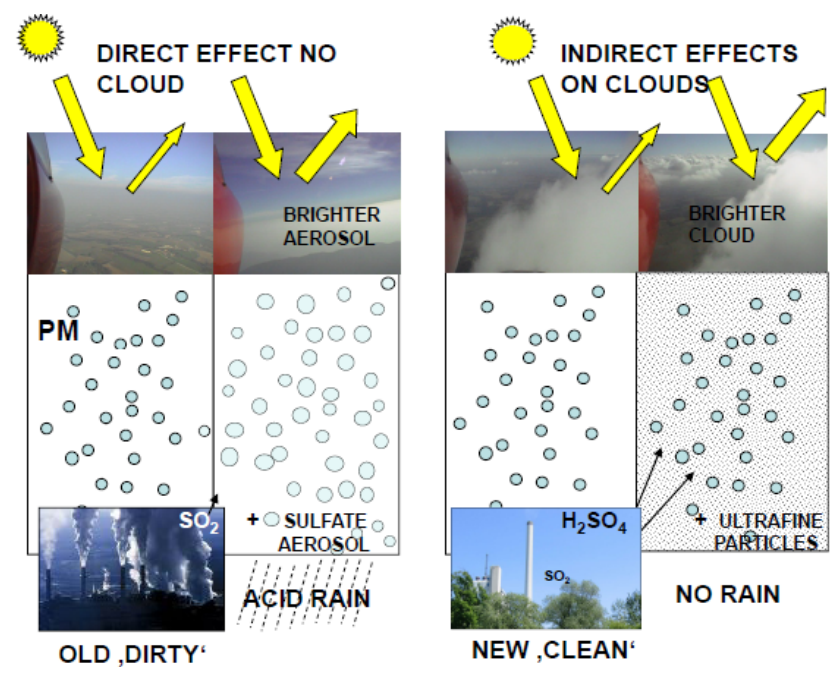

Fig. 1. Old versus new "clean" power plant emission: left (old power plant) - sulphur dioxide increases the size and scattering coefficient of particulate matter (PM), but not the number of existing or co-emitted particles; right (new power plant) - directly emitted $\mathrm{H}_{2} \mathrm{SO}_{4}$ increases the $\mathrm{CCN}$ number density and affects cloud microphysics by brighter clouds and precipitation suppression.

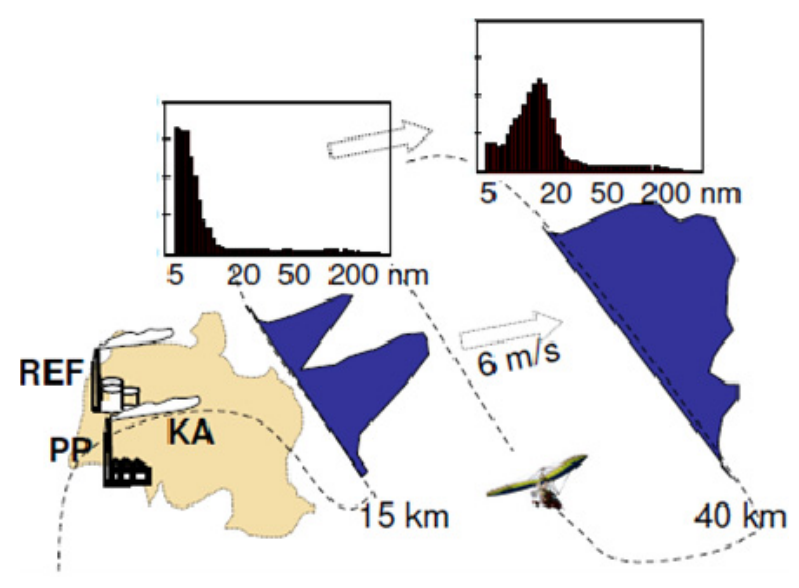

Fig. 2. Two point sources, one plume. Development of a particle plume at $500 \mathrm{~m}$ above ground from two elevated sources, the Karlsruhe (KA) power plant (PP) and the MIRO refinery (REF) after $15 \mathrm{~km}$ and $40 \mathrm{~km}$ of transport cross-sections (blue) and size distributions (black inserts). Maximum total numbers of ultrafine particles $(D>10 \mathrm{~nm})$ reach $\sim 50000 \mathrm{~cm}^{-3}$. These particles are expected to grow into CCN sizes after transport for another $\sim 100$ to $150 \mathrm{~km}$

For wind and turbulence, the DIMONA installation includes a BAT (Best Aircraft Turbulence) probe (Crawford et al. 1992), while the ultra-light aircraft carries a smaller version of a five-hole probe (Metzger et al. 2011), both combined with a fast, $100 \mathrm{~Hz}$, Inertial Navigation system RT3102, Oxford Technical Solutions, UK. For measurements over the boreal forest in Finland (Fig. 4), the SMPS was not yet available. Instead, the production of ultrafine 
Table 1. Aircraft instrumentation.

\begin{tabular}{llc}
\hline Parameter & Instrument & Time resolution \\
\hline Aerosol size distribution $D=5-350 \mathrm{~nm}$ & SMPS, GRIMM 5403 & $120 \mathrm{~s}$ \\
Aerosol size distribution $D=300 \mathrm{~nm}-20 \mu \mathrm{m}$ & OPC, GRIMM 1.108 & $6 \mathrm{~s}$ \\
Aerosol number concentration $D>10 \mathrm{~nm}$ & CPC, TSI3010 & $1 \mathrm{~s}$ \\
Extinction coefficient & Nephelometer HSS AVMIII & $1 \mathrm{~s}$ \\
Wind speed and direction & Turbulence probe & $0.1 \mathrm{~s}$ \\
Temperature, dew point & Chilled mirror, MeteoLab TP3 & $1 \mathrm{~s}$ \\
Radiation up- and down-welling & Pyranometer, Licor LI-200 & $1 \mathrm{~s}$ \\
Photolysis rates $J \mathrm{O}^{1} \mathrm{D}$ and $J \mathrm{NO}_{2}$ & actinic flux filterradiometers & $1 \mathrm{~s}$ \\
Cloud droplets (DIMONA only) & FSSP-100, DMT, Boulder, CO & $1 \mathrm{~s}$ \\
\hline
\end{tabular}

s, second; D, median particle diameter; SMPS, Scanning Mobility Particle Sizer; OPC, Optical Particle Counter; CPC, Condensation Particle Counter; FSSP, Forward Scattering Spectrometer Probe; AVMIII Airborne Visibility Meter.

particles was detected as the difference of two counters for particles larger than $3 \mathrm{~nm}$ (TSI, model 3025) provided by the University of Helsinki and $10 \mathrm{~nm}$ (TSI, model 3010).

Flight patterns were specifically designed for budget studies. On-board displays of the real time data during the flight were essential to adjust the flight patterns according to the actual weather and plume conditions and position.

\section{Results and discussion}

We analyzed airborne measurements of ultrafine particle size distributions in different regions of the world in order to investigate source strength, growth rates, and production rates of $\mathrm{CCN}$ from different emission sources. Within the COPS/TRACKS experiment we investigated the pollution plume of Karlsruhe, a medium-sized city in Germany with a population of 290,000. Here, two major sources of sulphur emissions are a $660 \mathrm{MW}$ coal-fired power plant and a large petrochemical refinery (PRTR, 2009). Our measurements revealed two distinct plumes of ultrafine particles with concentrations of up to 50,000 particles $\mathrm{cm}^{-3}$ merging into a single plume a few $\mathrm{km}$ downwind. However, neither an enhancement of the fine fraction larger than $D=300 \mathrm{~nm}$ or the number of accumulation mode particles larger than $100 \mathrm{~nm}$, nor increased scattering were observed (Junkermann et al., 2011). After about $2 \mathrm{~h}$ and $\sim 40 \mathrm{~km}$ transport, these particles grew to a mean particle size of about $D=20 \mathrm{~nm}$ (Fig. 2). Based on this Lagrangian study, we estimated an initial growth rate of $\sim 8 \mathrm{~nm} \mathrm{~h}^{-1}$, sufficient to generate thousands of mainly sulphuric acid based $\mathrm{CCN} \mathrm{cm}^{-3}$ in a size range larger than $50 \mathrm{~nm}$ within a few more hours and a particle source strength of $\sim 2 * 10^{18}$ particles $s^{-1}$. For this particle flux calculation we used the particles in the plume cross section multiplied by the measured wind speed (Table 2). It should be noted that the growth rate in the plume is possibly reduced during further dilution and plume dispersion. It's also dependent on the available $\mathrm{SO}_{2}$ and subsequent atmospheric conversion to $\mathrm{H}_{2} \mathrm{SO}_{4}$. Typical growth rates up to

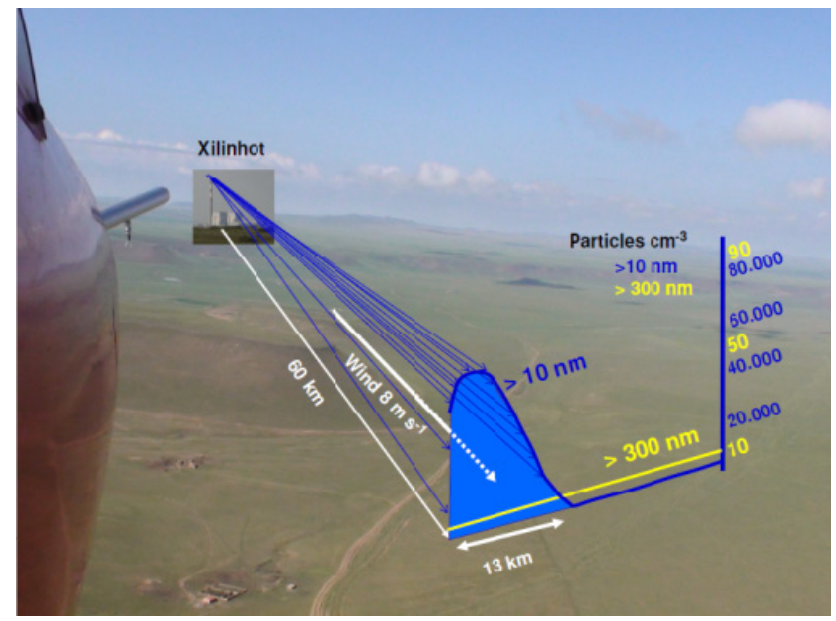

Fig. 3. Sketch of the ultrafine particle plume over the Inner Mongolian steppe downwind of Xilinhot (6 July 2009). Particle number density outside plume area $<1200 \mathrm{~cm}^{-3}$. Horizontal flight track $50 \mathrm{~m}$ above ground $40 \mathrm{~km}$. Blue: ultrafine particles, yellow: fine particles $D>300 \mathrm{~nm}$.

CCN sizes for sulphur polluted rich air masses outside of plumes are given by Wiedensohler et al (2009) as $6 \mathrm{~nm} / \mathrm{h}$.

Unexpectedly, compared with previous studies on new particle production (O'Dowd et al., 2009), fresh particles were emitted even in the late afternoon. This primary emission of ultrafine particles is independent of ambient conditions, because the particles are produced inside the stack already (Schulz and Smyrniotis, 2005) and do not require any radiation-dependent atmospheric initial nucleation reactions. However, particle growth after emission still depends on photochemical reactions, as is the case for natural biogenic new particle formation (Kulmala et al., 2004). During growth, these particles are then distributed regionally downwind, where they become effective as CCN. The atmospheric lifetime of these tiny particles is several days, enough for transport over more than $1000 \mathrm{~km}$. 
Table 2. Comparison of ultrafine particle production rates.

\begin{tabular}{lcll}
\hline Study site/area & Year & average annual particle production & Source type \\
\hline Karlsruhe "clean" power plant & 2007 & $2 \times 10^{18} \mathrm{~s}^{-1}$ & point \\
Xilinhot "clean" power plant & 2009 & $>7 \times 10^{18} \mathrm{~s}^{-1}$ & point \\
Port Augusta "clean" power plant & 2011 & $0.8^{*} 10^{18} \mathrm{~s}^{-1}$ & point \\
Four Corners "dirty" power plant & 1976 & $10^{15}-10^{16} \mathrm{~s}^{-1}$ & point \\
Motorway & 2004 & $4 \times 10^{14} \mathrm{~s}^{-1} \mathrm{~km}^{-1}$ & line \\
Boreal forest Hyytiälä, Finland & 2002 & $2 \times 10^{13} \mathrm{~s}^{-1} \mathrm{~km}^{-2}$ & area \\
\hline
\end{tabular}

Particle production rate ( $D=20 \mathrm{~nm}, \mathrm{CCN}$ precursors), power plants operating $24 \mathrm{~h}$ per day $\left(\mathrm{hd}^{-1}\right)$, motorway $15 \mathrm{hd}^{-1}$, boreal forest nucleation $3 \mathrm{~h} \mathrm{~d} \mathrm{~d}^{-1}$ on $25 \%$ of all days calculated as annual average production $\mathrm{s}^{-1}$. "Dirty" power plant study, $(D>50 \mathrm{~nm}, \mathrm{CCN})$.

The process is not limited to the studied power plant in Germany. We found similar particle plumes with even higher numbers of ultrafine particles during recent airborne experiments in 2009 over the pristine grasslands of Inner Mongolia (Fig. 3). While background number counts of ultrafine particles over the steppe were $\sim 800-1200 \mathrm{~cm}^{-3}$, far lower than those found in Germany and close to the natural continental background level, we observed up to 80000 ultrafine particles $\mathrm{cm}^{-3}$ on more than $50 \%$ of the flying days of the experiments in Inner Mongolia, always downwind of a "modern" coal-fired power plant about $60 \mathrm{~km}$ northwest of our research area. Again, the number of fine, visible particles, $D>300 \mathrm{~nm}$, remained unaffected on a very low level $\left(<15\right.$ particles $\left.\mathrm{cm}^{-3}\right)$. The particle production rate from this source was even higher than that in Karlsruhe (Table 2). Overall, these data demonstrate a substantial emission of ultrafine particles from "clean" large fossil fuel combustion plants. Although this emission amounts to less than $3 \%$ of the total power plant sulphur emission, it is increasing the number of sulphur-related cloud condensation nuclei by up to an order of magnitude depending on the regional $\mathrm{CCN}$ background.

Similarly, in a third plume experiment in South Australia we were able to detect a particle plume originating from the Port Augusta coal fired power plant while travelling on the road with the instrumentation described in Table 1. The source strength of this small $(250 \mathrm{MW})$ plant was estimated to $0.8 \times 10^{18}(D=20 \mathrm{~nm})$ particles $\mathrm{s}^{-1}$. As the particle emission from power plants happens at about $200 \mathrm{~m}$ above ground and is subject to an additional altitude gain due to the high temperatures of the flue gas, the injection height into the atmosphere is typically about $350 \mathrm{~m}$. Even under convective conditions in the vicinity of the source these emissions are not detectable on the ground. It takes about 8 to $10 \mathrm{~km}$ of transport before such a plume becomes visible with ground based instrumentation. In the Australian experiment we crossed the plume about $40 \mathrm{~km}$ from the source. This is different from the "old" plume investigations where a visible plume can be seen and followed only under stable conditions. The measurements presented here were all done under highly convective conditions with rapid mixing throughout the whole planetary boundary layer.

The importance of this local anthropogenic particle production can be assessed by comparing the particle numbers produced in the "clean" power plant plumes with those found during other investigations where ultrafine particles were of either anthropogenic or natural origin. Typical examples given in the following are plume studies from coal combustion before flue gas cleaning procedures were implemented (Pueschel and Van Valin, 1978), motorway traffic emissions (Rosenbohm et al., 2005, Imhoff et al., 2005), and biogenic nucleation events as observed over boreal forests (O'Dowd et al., 2009) (Table 2).

Pueschel and Van Valin (1978) performed studies during several campaigns between 1973 and 1976. The "dirty" plants studied at that time emitted large quantities of sulphur dioxide and visible fine and coarse aerosols. Although the total sulphur emission was more than an order of magnitude larger in 1976 compared with that of the 2007 Karlsruhe plume, the total number of cloud condensation nuclei, measured with a CCN counter, was significantly lower. For a power plant much larger than that at Karlsruhe (Four Corners, TX, $2200 \mathrm{MW}), 10^{15}-10^{16}$ particles per second in CCN size ( $D>50 \mathrm{~nm}$ for sulphuric acid particles) were estimated. At that time, this value was considered to be comparable to the natural production of $\mathrm{CCN}$ from that power plant's entire $\sim 10000 \mathrm{~km}^{2}$ plume area. The total production rate of $20 \mathrm{~nm}$ aerosols from the two "clean" point sources in our Karlsruhe plume, by contrast, was three orders of magnitude higher (Table 2).

Traffic emissions are another major anthropogenic source of ultrafine particles. Cars emit particles in the $D=15-$ $20 \mathrm{~nm}$ range. From measurements alongside a busy motorway north of Karlsruhe (Rosenbohm et al., 2005; Imhoff et al., 2005), the source strength during the day can be estimated to be up to $\sim 4 \times 10^{14} \mathrm{~s}^{-1} \mathrm{~km}^{-1}$ at a car frequency of 60000 cars day $^{-1}$, much lower at night. Here we used the data published and calculated the source strength of the line emission source based on the concentrations, vertical distributions and wind speeds given in these papers. Compared to 
the motorway line source, one "clean" power plant produces a similar amount of ultrafine particles as $\sim 1 / 3$ of the German motorway system $(12000 \mathrm{~km}$, highways only) (Table 2).

Ultrafine particles acting as sources for $\mathrm{CCN}$ are produced naturally as well from DMS emissions over the oceans as from biogenic emissions over the continents. This biogenic particle production is also the source of the typical blue haze over continental forest ranges (Rasmussen and Went, 1965). The continental particles originate from regionally distributed sources over forests during new particle formation which is frequently occurring in short time nucleation bursts (Kulmala et al., 2004). A single "typical" nucleation event over the boreal forest in Hyytiälä, Finland in spring 2003 produced $\sim 8000$ new particles $\mathrm{cm}^{-3}$ with a mean size of $20 \mathrm{~nm}$, well distributed within the $800 \mathrm{~m}$ planetary boundary layer. These measurements were performed by continuous vertical profiles flown between about $5 \mathrm{~m}$ above the ground to the free troposphere during the built up of the mixed layer using the microlight aircraft in the vicinity of the Hyytiälä SMEAR station (Fig. 4). The flights also covered the vicinity of the station with a mixture of forests and lakes up to about $30 \mathrm{~km}$ in diameter. At that time of the year the lakes were still covered with a thick ice layer. Maximum number densities of $\mathrm{D}=20 \mathrm{~nm}$ particles were reached about three hours after the initiation of nucleation. Hence, the total number of biogenic ultrafine particles injected into the planetary boundary layer was in the order of $\sim 10^{15}$ particles km $\mathrm{km}^{-2} \mathrm{~s}^{-1}$. However, nucleation requires dry sunny and preferably cold conditions that prevail at that location on about 90 days per year only (Manninen et al., 2010), while a nucleation event typically lasts only $2-3 \mathrm{~h}$. The annual average particle source strength over boreal forest is thus about $2 \times 10^{13} \mathrm{~s}^{-1} \mathrm{~km}^{-2}$, comparable to Pueschel and Van Valin's (1978) old power plant plume area estimates (Table 2). As new particle production from biogenic precursors is facilitated in the presence of anthropogenic sulphuric acid (Zhang et al., 2009; Paasonen et al., 2010) this possibly is an upper estimate for biogenic production in the area.

Ultrafine particle production from "clean" fossil fuel thus turns out to be one of the main anthropogenic sources of cloud condensation nuclei. One "clean" power plant ( $\sim 600 \mathrm{MW}$ electricity production) produces as many ultrafine particles as about $4000 \mathrm{~km}$ of motorway, or as half of the boreal forest area in Finland. This is due to the change from "dirty" power generation to "clean" operation, which reduces the total sulphur emissions, while the production of CCN precursors is considerably increased. Power plant particle productions are even more important as they emit effectively into mid-elevations of the planetary boundary layer, where the particles are much less likely to be rapidly deposited than those produced at ground level and have a high probability to end up as $\mathrm{CCN}$.

These results also explain why concurrent with the significant reduction of $\mathrm{SO}_{2}$ emissions in Europe in the last decades, the few available data show that the number of
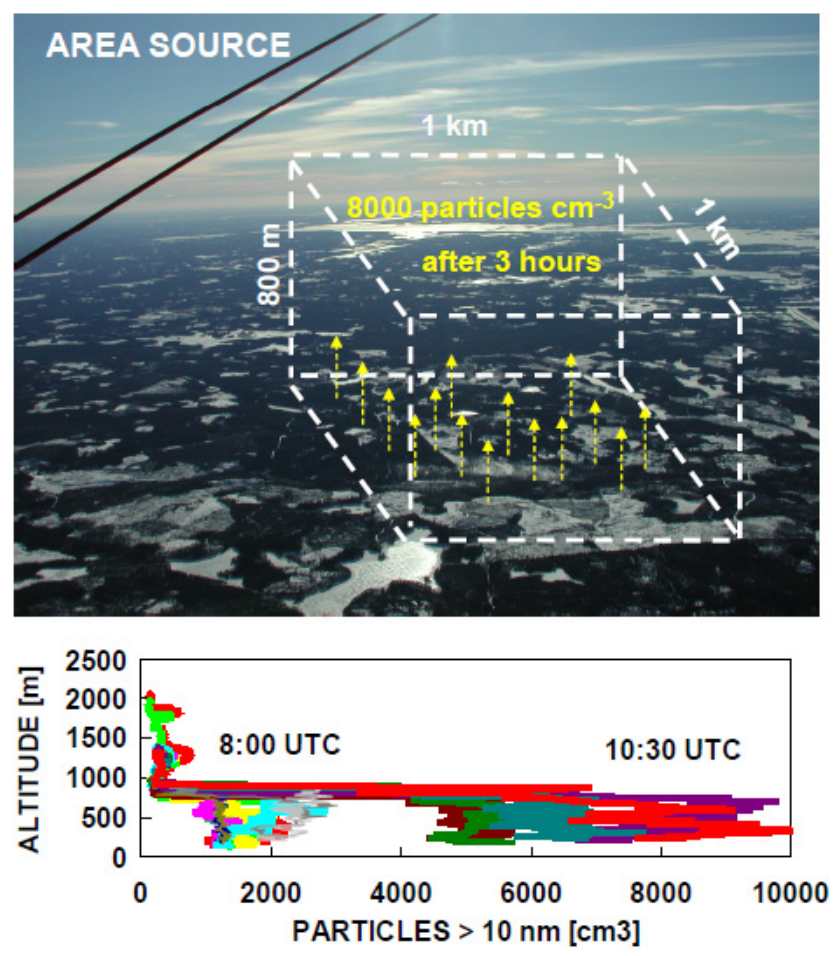

Fig. 4. Particle production over the boreal forest of Finland. 20 consecutive vertical profiles were flown over and in the vicinity of the ground based station of Hyytiälä between the free troposphere and about $5 \mathrm{~m}$ above ground to follow the development of the particle number concentrations and the growth of the mixed layer in the morning. (b) shows the individual profiles, marked by different colors, of particles in the $D>10 \mathrm{~nm}$ range, final $D>3 \mathrm{~nm}$ particles up to $35000 \mathrm{~cm}^{-3}$ (not shown). Brown, yellow and violet profiles below 2000 particles $/ \mathrm{cm}^{3}$ were flown before the onset of nucleation, brown and green with $\sim 5000 \mathrm{~cm}^{-3}$ during the event over the lakes, profiles with more than $8000 \mathrm{~cm}^{-3}$ over the forest towards the end of the event.

$\mathrm{CCN}$ at ground level decreased only marginally (Hamed et al., 2010).

Enhanced CCN number concentrations can increase the cloud albedo (Twomey, 1974), partially compensating the loss of additional scattering by sulphate coatings on preexisting aerosols (Arneth et al., 2009). However, it is also important to consider the precipitation effects of the increased $\mathrm{CCN}$ numbers. Experiments are scarce, as long-term, largescale monitoring of aerosols and precipitation is required. We performed additional airborne experiments on the interaction of particles and $\mathrm{CCN}$ with clouds and precipitation over one of the very few regions suitable for such experiments in the world, the South West of Western Australia. Here, two adjacent homogeneous land use areas divided merely by a fence and both spanning several thousands of $\mathrm{km}^{2}$ allow for direct comparisons of the effect of land use on CCN and related precipitation patterns. The fence separates an agricultural area suffering from a reduction of 
precipitation from a natural forest showing a slight increase in precipitation in the last decades. Long-term, statistically significant precipitation data are available for this area. We were able to relate the reduction in precipitation to the largescale land use change associated with a doubling of the CCN number concentration (Junkermann et al., 2009).

Model calculations of the particle growth in the Karlsruhe power plant plume confirm the experimental results observed as shown by our application of the regional model COSMOART (Vogel et al., 2009). Applied to the aerosol production in the Karlsruhe power plant plume case our model reproduces well both, the growth of the ultrafine particles in the plume and the dependence on the emission altitude. Changing from pure $\mathrm{SO}_{2}$ to $97 \% \mathrm{SO}_{2}$ and $3 \% \mathrm{H}_{2} \mathrm{SO}_{4}$ (gas phase) emission (Schulz and Smyrniotis, 2005), doubles the number of particles and increases their size by $40 \%$. This tendency would be even stronger for a direct emission of $1 \mathrm{~nm}$ droplets instead of $\mathrm{H}_{2} \mathrm{SO}_{4}$ molecules. Emission into altitudes of 300 to $500 \mathrm{~m}$ agrees well with the observations and was confirmed to increase the efficiency of $\mathrm{CCN}$ production, as particle deposition on the ground does not play a major role any more (Junkermann et al., 2011).

Due to the long-range transport of the ultrafine particles for several days and the $6-8 \mathrm{~h}$ required to grow to $\mathrm{CCN}$, local effects are sparse, but anthropogenic $\mathrm{CCN}$ effects can be expected on regional or even larger scales. Lower growth rates would only shift the onset of the cloud impact slightly further downwind from the source region. We found that a doubling of $\mathrm{CCN}$ in pristine Western Australia led to a regional reduction in precipitation by $\sim 20 \%$. Also and irrespective of the recent floods, a regional decline of precipitation by $40 \%$ since 1970 is reported for Northeastern Australia, which is claimed to be linked to regional aerosol air pollution (Bigg, 2008), although concurrent aerosol measurements are lacking. Within the last $40 \mathrm{yr}$, however, more than 10 large coalfired power plants were taken into operation in the area.

To indicate the magnitude of the ultrafine particle emissions by single power plants we can compare the plant emissions with requirements for particle production in global solar radiation management (SRM) proposals. The climate impact of increasing numbers of $\mathrm{CCN}$ is currently under intense discussion in regard to geo-engineering activities to modify the albedo of marine stratocumulus clouds in order to counteract global warming. Recent global models propose a possible continental-to-global shift of precipitation as a result of such artificial regional increases of maritime CCN (Bala et al., 2008; Keith et al., 2010). In these simulations, the earth's surface is divided into 6596 cells of $7.7 \times 10^{4} \mathrm{~km}^{2}$ each. SRM-experiments would require to triple the number of $\mathrm{CCN}$ in about $15 \%$ of the marine cells, generating additionally $1.2 \times 10^{17} \mathrm{~s}^{-1}$ particles per cell, proposed to be produced by spraying seawater into tiny droplets of $\sim 800 \mathrm{~nm}$ size (Salter et al., 2008). This size depends on the technical problems to spray seawater in tiny droplets. Smaller droplets would be as effective.
One power plant of the Karlsruhe size would be sufficient per cell even under the slightly enhanced pre-existing CCN numbers to double the $100-250 \mathrm{~cm}^{-3} \mathrm{CCN}$ over pristine continental regions compared to $40-60 \mathrm{~cm}^{-3}$ over the oceans assuming that a small sulphuric acid CCN of $50 \mathrm{~nm}$ is as efficient as a fine seawater droplet.

When extrapolating from the conditions measured at single power plants in Europe, Inner Mongolia and Australia, the large number of already operational or planned "clean" coal-fired power plants in China, which is covering the size of 130 cells (Inner Mongolia $\sim 15$ cells) would be sufficient for a regional continental solar radiation management project (Latham et al., 2008; Salter et al., 2008). Although they may not yet be statistically significant, the shifts in precipitation intensity and distribution adversely affect agricultural production already now (Zhao and Running, 2010; Piao et al., 2010).

\section{Summary and conclusions}

We carried out airborne studies to quantify the budget of ultrafine particles as cloud condensation nuclei $(\mathrm{CCN})$ precursors. We found that modern implementations of fossil fuel (coal) burning power plants are one of the major sources of ultrafine particles in the planetary boundary layer on a regional scale exceeding other known major sources. We considered $20 \mathrm{~nm}$ particles as a proxy for CCN precursors to be able to compare with other sources. Sulphuric acid particles would need to grow further to approximately $50 \mathrm{~nm}$ before they can be activated as $\mathrm{CCN}$, possibly slightly reducing the numbers due to coagulation processes. However the total numbers of particles produced by "clean" power plants are so large that our comparison analysis would not be affected. "Clean" technology coal fired power plants turned out to be the major sources of ultrafine particles in mid elevations of the planetary boundary layer in pristine and moderately polluted conditions. Only in very highly polluted regions other industrial sources could possibly compete. Here a loss to pre-existing accumulation mode particles during plume dispersion can also be significant. The process is not limited to coal fired power plant. It happens also in refineries (Rosenfeld, 2000; Junkermann et al., 2011).

Although cleaning of flue gas to reduce $\mathrm{SO}_{2}$, sulphate and nitrogen dioxide oxide emissions is mandatory to protect the environment from acidification of rain, our results show that the technique currently used has some less beneficial side effects. The enhanced number of CCN might partially compensate the loss in aerosol scattering by an increase in the brightness of clouds. Probably, the most important unanticipated implication of cleaning fossil fuel power plant emissions on the regional scale is the reduction or even suppression of steady, low-intensity precipitation. This does not necessarily change the total precipitation amount, but the precipitation's spatial and intensity distribution (Rosenfeld et al., 
2008). The water trapped temporarily in the atmosphere either in the gas phase or in tiny droplets too small to produce rain can be effectively transported over large distances. Finally under conditions with additional forcing of precipitation production, for example by orography, it favours more intense rainfall or even vigorous flooding which can take place thousands of kilometers away. These effects, especially their localisation, are still rather uncertain among the few available global models (Jones et al., 2009) and were not covered by our regional scale model calculations.

Modern "clean" plants in the near future will replace the remaining old "dirty" facilities in industrialised countries, while developing countries will directly install "clean"” new plants. As they are still considered to be clean, new coal fired power plants are now also being constructed in extremely sensitive semi-arid agricultural regions close to the coal mines (China Post, 2009, http://www.power-technology. $\mathrm{com} /$ projects/kogan/), where additional ultrafine particulate emissions might have severe negative consequences on the regional water budget.

The analysis we report here is thus important in highlighting an unexpected effect of clean technology. While reducing sulphur emissions is well known to be associated with a climate penalty through light scattering effects (Arneth et a, 2009), our results show that flue cleaning technology actually introduces a new problem, in the form of increased emissions of ultrafine particles. By creating an oversupply of cloud condensation nuclei, these provide an additional mechanism to alter climate directly, by altering precipitation patterns.

Acknowledgements. We acknowledge support by Deutsche Forschungsgemeinschaft and Open Access Publishing Fund of Karlsruhe Institute of Technology.

Edited by: M. Krämer

\section{References}

Adams P. J. and Seinfeld J. H.: Disproportionate impact of particulate emissions on global cloud condensation nuclei concentrations, Geophys. Res. Lett., 30, doi:10.1029/2002GL016303, 2003.

Arneth, A., Unger, N., Kulmala, M., and Andreae M. O.: Clean the Air, Heat the Planet?, Science, 326, 672-673, 2009.

Bala G., Duffy, B., and Taylor, K. E.: Impact of geoengineering schemes on the global hydrological cycle, PNAS, 105, 76647669, 2008.

Bigg, E. K.: Trends in rainfall associated with sources of air pollution, Environ. Chem., 5, 184-193. doi:10.1071/EN07086, 2008.

Birmili, W., Berresheim, H., Plass-Dülmer, C., Elste, T., Gilge, S., Wiedensohler, A., and Uhrner, U.: The Hohenpeissenberg aerosol formation experiment (HAFEX): a longterm study including size-resolved aerosol, $\mathrm{H} 2 \mathrm{SO} 4, \mathrm{OH}$, and monoterpenes measurements, Atmos. Chem. Phys., 3, 361-376, doi:10.5194/acp-3-361-2003, 2003.
China Post, http://www.chinacsr.com/en/2009/09/03/, last access: November 2011, 2009.

Feingold, G. and Siebert, H.: Cloud-aerosol interactions from the micro to the cloud scale, in: CLOUDS IN THE PERTURBED CLIMATE SYSTEM, edited by: Heinzenberg, J. and Charlson, R., MIT Press, Cambridge, USA, 2009.

Flossmann, A. and Wobrock, W.: A review of our understanding of the aerosol-cloud interaction from the perspective of a bin resolved cloud scale modelling, Atmos. Res., 97, 478-497, 2010.

Hamed, A., Birmili, W., Joutsensaari, J., Mikkonen, S., Asmi, A., Wehner, B., Spindler, G., Jaatinen, A., Wiedensohler, A., Korhonen, H., Lehtinen, K. E. J., and Laaksonen, A.: Changes in the production rate of secondary aerosol particles in Central Europe in view of decreasing $\mathrm{SO}_{2}$ emissions between 1996 and 2006, Atmos. Chem. Phys., 10, 1071-1091, doi:10.5194/acp-10-10712010, 2010.

Imhof, D., Weingartner, E., Vogt, U., Dreiseidler, A., Rosenbohm, E., Scheer, V., Vogt, R., Nielsen, O.J., Kurtenbach, R., Corsmeier, U., Kohler, M., and Baltensperger, U.: Vertical distribution of aerosol particles and $\mathrm{NO}_{\mathrm{x}}$ close to a motorway, Atmos. Environ., 39, 5710-5721, 2005.

Jones, A., Haywood, J., and Boucher, O.: Climate impacts of geoengineering marine stratocumulus clouds, J. Geophys. Res., 114, D10106, doi:10.1029/2008JD011450, 2009.

Junkermann, W.: An ultralight aircraft as platform for research in the lower troposphere: system performance and first results from radiation transfer studies in stratiform aerosol layers and broken cloud conditions, J. Ocean. Atmos. Techn., 18. 934-946, 2001.

Junkermann, W., Hacker, J., Lyons, T., and Nair, U.: Land use change suppresses precipitation, Atmos. Chem. Phys., 9, 65316539, doi:10.5194/acp-9-6531-2009, 2009.

Junkermann, W., Hagemann, R., and Vogel, B.: Nucleation in the Karlsruhe plume during the COPS/TRACKS - Lagrange experiment, Q. J. Roy. Meteorol. Soc., 137, 267-274, 2011.

Kazil, J., Stier, P., Zhang, K., Quaas, J., Kinne, S., O’Donnell, D., Rast, S., Esch, M., Ferrachat, S., Lohmann, U., and Feichter, J.: Aerosol nucleation and its role for clouds and Earth's radiative forcing in the aerosol-climate model ECHAM5-HAM, Atmos. Chem. Phys., 10, 10733-10752, doi:10.5194/acp-1010733-2010, 2010.

Khain, A. P.: Notes on the state-of-the-art investigations of aerosol effects on precipitation: a critical review, Environ. Res. Lett., 4, 1-20, 2009.

Keith, D. W., Parson, E., and Morgan, M. G.: Research on global sun block needed now, Nature, 463, 426-427, 2010.

Konwar, M., Maheskumar, R. S., Kulkarni, J. R., Freud, E., Goswami, B. N., and Rosenfeld, D.: Suppression of warm rain by aerosols in rain-shadow areas of India, Atmos. Chem. Phys. Discuss., 10, 17009-17027, doi:10.5194/acpd-10-17009-2010, 2010.

Kulmala, O., Laakso, L., Lehtinen, K. E. J., Riipinen, I., Dal Maso, M., Anttila, T., Kerminen, V.-M., Hrrak, U., Vana, M., and Tammet, H.: Initial steps of aerosol growth, Atmos. Chem. Phys. Discuss., 4, 5433-5454, doi:10.5194/acpd-4-5433-2004, 2004.

Latham, J., Rasch, P., Chen, C.-C., Kettles, L., Gadian, A., Gettelman, A., Morrison, H., Bower, K., and Choularton, T.: Global temperature stabilization via controlled albedo enhancement of low-level maritime clouds. Phil. Trans. R. Soc. A, 366, 39693987, 2008. 
Lelieveld, J. and Heintzenberg, J.: Sulphate Cooling Effect in Climate Through In-Cloud Oxidation of Anthropogenic $\mathrm{SO}_{2}$, Science, 258, 117-120, 1992.

Liepert B. G., Feichter J., Lohmann U., and Roeckner E.: Can aerosols spin down the water cycle in a warmer and moister world?, Geophys. Res. Lett., 31, L06207, doi:10.1029/2003GL019060, 2004.

Lohmann, U., Feichter, J., Chuang, C. C., and Penner, J.: Prediction of the number of cloud droplets in the ECHAM GCM, J. Geophys. Res., 104, 9169-9198, 1999.

Lohmann, U., Feichter, J., Penner, J., and Leaitch, R.: Indirect effect of sulphate and carbonaceous aerosols: a mechanistic treatment, J. Geophys. Res., 105, 12193-12206. 2000.

Manktelow, P. T., Carslaw, K. S., Mann, G. W., and Spracklen, D. V.: Variable CCN formation potential of regional sulfur emissions, Atmos. Chem. Phys., 9, 3253-3259, doi:10.5194/acp-9-3253-2009, 2009.

Manninen, H. E., Nieminen, T., Asmi, E., Gagn, S., Hkkinen, S., Lehtipalo, K., Aalto, P., Vana, M., Mirme, A., Mirme, S., Hõrrak, U., Plass-Dlmer, C., Stange, G., Kiss, G., Hoffer, A., Törö, N., Moerman, M., Henzing, B., de Leeuw, G., Brinkenberg, M., Kouvarakis, G. N., Bougiatioti, A., Mihalopoulos, N., O'Dowd, C., Ceburnis, D., Arneth, A., Svenningsson, B., Swietlicki, E., Tarozzi, L., Decesari, S., Facchini, M. C., Birmili, W., Sonntag, A., Wiedensohler, A., Boulon, J., Sellegri, K., Laj, P., Gysel, M., Bukowiecki, N., Weingartner, E., Wehrle, G., Laaksonen, A., Hamed, A., Joutsensaari, J., Petäjä, T., Kerminen, V.-M., and Kulmala, M.: EUCAARI ion spectrometer measurements at 12 European sites - analysis of new-particle formation events, Atmos. Chem. Phys. Discuss., 10, 11251-11313, doi:10.5194/acpd10-11251-2010, 2010.

Murphy, J. T.: http://www.coalpowermag.com/ November 2011, 2007.

O’Dowd, C. D., Yoon, Y. J., Junkermann, W., Aalto, P., Kulmala, M., Lihavainen, H., and Viisanen, Y.: Airborne measurements of nucleation mode particles II: boreal forest nucleation events, Atmos. Chem. Phys., 9, 937-944, doi:10.5194/acp-9-937-2009, 2009.

Paasonen, P., Nieminen, T., Asmi, E., Manninen, H. E., Petäjä, T., Plass-Dlmer, C., Flentje, H., Birmili, W., Wiedensohler, A., Hõrrak, U., Metzger, A., Hamed, A., Laaksonen, A., Facchini, M. C., Kerminen, V.-M., and Kulmala, M.: On the roles of sulphuric acid and low-volatility organic vapours in the initial steps of atmospheric new particle formation, Atmos. Chem. Phys., 10, 11223-11242, doi:10.5194/acp-10-11223-2010, 2010.

Piao, S., Ciais, P., Huang, Y., Shen, Z., Peng, S., Li, J., Zhou, L., Liu, H.,Ma, Y., Ding, Y.,Friedlingstein, P. Liu, C., Tan, K., Yu, Y., Zhang, T., and Fang, J.: The impacts of climate change on water resources and agriculture in China, Nature, 467, 43-51, doi:10.1038/nature09364, 2010.

PRTR, Deutsches Schadstofffreisetzungs- und -verbringungsregister (German registry of release and disposal of pollutants), Umweltbundesamt, available online at: www.prtr.bund.de, 2009,

Pueschel, R. F. and Van Valin C. C.: Cloud nucleus formation in a power plant plume, Atmos. Environ., 12, 307-312, 1978.
Rasmussen, R. A. and Went, F. W.: Volatile organic material of plant origin in the atmosphere, Proc. Natl. Acad. Soc. USA, 53, 215-220, 1965.

Rosenbohm, E., Vogt, R., Scheer, V., Nielsen, O. J., Dreiseidler, A., et al.: Particulate size distributions and mass measured at a motorway during the BAB II campaign, Atmos. Environ., 39, 5696-5709, 2005.

Rosenfeld, D.: Suppression of Rain and Snow by Urban and Industrial Air Pollution, Science, 287, 1793, 2000.

Rosenfeld, D., Lohmann, U., Raga, G. B., O’Dowd C. D., Kulmala, M., Fuzzi, S., Reisell, A., and Andreae, M. O.: Flood or Drought: How Do Aerosols Affect Precipitation?, Science, 321, 1309-1313, 2008.

Salter, S., Sortino, G., and Latham, J.: Sea-going hardware for the cloud albedo method of reversing global warming, Phil. Trans. R. Soc. A, 366, 3989-4006, 2008.

Schulz, K. W. and Smyrniotis, C. R.: Controlling $\mathrm{SO}_{3}$ in Coal and Oil Fired Utility Boilers: Technology and Experience, Paper Presented at the EERC International Conference on Mercury, Trace Elements, $\mathrm{SO}_{3}$, and Particulate Matter, September 2005, Arlington, VA, USA, available online at: www.ftek.com/pdfs/TPP-570. pdf, 2005.

Srivastava, R. K., Miller, C. A., Erickson, C., and Jambhekar, R.: Emissions of sulfur trioxide from coal-fired power plants, J. Air Waste Manage. Assoc., 54, 750-762, 2004.

Twomey, S.: Pollution and the planetary albedo, Atmos. Environ., 8, 1251-1256, 1974.

Vogel, B., Vogel, H., Bäumer, D., Bangert, M., Lundgren, K., Rinke, R., and Stanelle, T.: The comprehensive model system COSMO-ART - Radiative impact of aerosol on the state of the atmosphere on the regional scale, Atmos. Chem. Phys., 9, 86618680, doi:10.5194/acp-9-8661-2009, 2009.

Wang, H., Rasch, P. J., and Feingold, G.: Manipulating marine stratocumulus cloud amount and albedo: a process-modelling study of aerosol-cloud-precipitation interactions in response to injection of cloud condensation nuclei, Atmos. Chem. Phys., 11, 42370-4249, doi:10.5194/acp-11-4237-2011, 2011.

Wiedensohler, A., Cheng, Y. F. Nowak, A., Wehner, B., Achtert, P., Berghof, M., Birmili, W., Wu, Z. J., Hu, M., Zhu, T., Takegawa, N., Kita, K., Kondo, Y., Lou, S. R., Hofzumahaus, A., Holland F., Wahner, A., Gunthe, S. S., Rose, D., Su, H., and Pöschl, U., Rapid aerosol particle growth and increase of cloud condensation nucleus activity by secondary aerosol formation and condensation: A case study for regional air pollution in northeastern China, J. Geophys. Res., 114, D00G08, doi:10.1029/2008JD010884, 2009.

Zhao, M. and Running, S. W.: Drought-induced reduction in global terrestrial net primary production from 2000 through 2009, Science, 329, 940-943, 2010.

Zhang, R., Wang, L., Khalizov, A. F., Zhao, J., Zheng, J., McGraw, R. L., and Molina, L.: Formation of nanoparticles of blue haze enhanced by anthropogenic pollution, PNAS, 106, 1765017654, doi:10.1073/pnas.0910125106, 2009. 